\title{
UPAYA PENGELOLA LKP SRIKANDI DALAM MENINGKATKAN KOMPETENSI PROFESIONAL PESERTA TATABUSANA MELALUI PENDEKATAN ANDRAGOGI
}

\author{
${ }^{1}$ Dini apriani, ${ }^{2}$ Ansori \\ 1,2 IKIP SILIWANGI \\ 1aprianidini488@gmail.com
}

\begin{abstract}
ABSTRAK
LKP Srikandi bertempat di kelurahan Padasuka Cimahi Tengah, LKP ini menyelenggarakan program kursus unggulan yaitu tata boga dan tata busana. Penelitianbertujuan untuk mengetahui apakah terdapat peningkatan kompetensi profesionalpeserta kursus tata busana.Penelitian ini termasuk penelitian kualitatif. Metodepenelitian menggunakan metode kualitatif dengan pendekatan Andragogi. Variabel independen yaitu upaya pengelola LKP Srikandi. Sementara variabel dependent adalah peningkatan kompetensi profesional peserta kursus tata busana. Populasi pada penelitian adalah semua peserta tata busana di LKP Srikandi dengan sampel peserta kursus tata busana yang berjumlah 5 orang peserta. Hasilpenelitian ini (1) menunjukan adanya kondisi yang lebih menyenangkan dalam belajar menjahit (2) pengelolalebih inovatif dalam memberikan pengarahan, peningkatan keterampilan(3) peningkatan kompetensi profesional peserta didik dalam bidang tata busana berupa kemajuan pengetahuan dan pemahaman mengenai keterampilan yang didapat serta peningkatan ketiga aspek yaitu kognitif, psikomotor dan afektif.
\end{abstract}

Kata kunci : Lembaga Kursus dan Pelatihan, Kompetensi Profesional, Pendekatan Andragogi

\section{PENDAHULUAN}

Pendidikan merupakan kebutuhan mendasar bagi setiap individu khususnya untuk menunjang kehidupannya. Karna pendidikan sendiri berdampak besar bagi umat manusia dalam hal perkembangan teknologi. Seluruh warga Indonesia mempunyai hak dan kewajiban terhadappendidikan itu sendiri. Pendidikan adalah suatu kebutuhan yang sangat mendasar untuk meningkatkan kualitas manusia seutuhnya. Hal tersebut sesuai dengan UUD 1945 Pasal 30 Ayat 1 yang berbunyi " tiap-tiap warga negara berhak mendapatkan pendidikan yang layak".dapat diartikan bahwa pendidikan pada hakekatnya memberikan pengaruh secara sengaja dan dilakukan dengan sadar untuk mengembangkan kepribadian jasmani dan rohani individu agar mencapai tingkat yang lebih baik dan menjadi manusia dewasa yang bertanggung jawab.

Sumberdaya manusia merupakan faktor yang menunjang dalam kehidupan manusia. Baik berupa kebutuhan sandang, pangan dan juga papan. Banyak masyarakat yang berusia produktif diwilayah Indonesia khususnya, namun belum bisa mengoptimalkan sumberdaya yang dimiliki. Bahkantingkat kemiskinan diwilayah Indonesia sendiri semakin meningkat dikarenakan faktor setiap individu yang belum bisa 
mengoptimalkan keterampilan yang dimiliki. Usiaproduktif merupakan aset yang berharga bagi perkembangan tingkat pendapatan negara Indonesia dimana life skill yang dimiliki akan dijadikan sebagai faktor utama penunjang yang akan membantu Indonesia menjadi negara maju.MasyarakatIndonesia menginginkan mayarakatnya untuk bisa membuka peluang usaha baru dari keterampilan yang dimiliki dan dari potensi sumberdaya manusia itu sendiri.

Kesenjangan sosial mengakibatkan pendapatan yang diperoleh oleh masyarakat tidak seimbang karna pendapatan yang diperoleh lebih kecil dari pada kebutuhan. Sehingga munculah masalah yang dihadapi oleh masyarakat saat ini. Antara kenyataan dan harapan tidak sesuai dengan kenyataan yang didapat. Sedangkan dalam kenyataannya bahwa setiap individu dituntut untuk memiliki keahlian yang nantinya dapat diterapkan dilingkungan sosial yang akan menunjang dirinya dimasa depan. Keterampilan dan peningkatan kompetensi merupakan modal yang dapat dikembangkan oleh setiap individu. Sehingga individu mampu menciptakan karya hasil buah tangan atas dasar keterampilan yang diperoleh dari pelatihan tersebut.

Sebagai lembaga pendidikan nonformal LKP merupakan wadah yang memberikan fasilitas bagi masyarakat agar dapat meningkatkan keterampilan dan mengembangkan potensi yang dimiliki. Sebagai tempat untuk memberdayakan masyarakat khususnya usia produtif yang belum memiliki pekerjaan. LKP didirikan dengan memperhatikan sumber-sumber potensi yang ada pada daerah wilayah setempat sehingga dapat disesuaikan dengan kebutuhan masyarakat sendiri. Sehingga LKP merupakan sarana yang tepat digunakan untuk masyarakat agar dapat mengoptimalkan sumberdaya yang dimiliki melalui kursus dan pelatihan, misalnya kursus tata boga, kursus tata busana, hantaran, akrilik dan lain sebagainya.

Secara umum proses kursus dan pelatihan tata busana masih menggunakan metode atau cara belajar ceramah sebelum ke tahap praktek sebagai tahap dasar tentang sumber pengetahuan. Hal tersebut mengakibatkan peserta kursus dan pelatihan tata busana menjadi bosan melakukan kegiatan pelatihan dan akhirnya kurang berminat untuk mengikuti pelatihan. Menciptakan suasana pelatihan yang menarik dan membuat peserta kursus dan pelatihan bersemangat adalah dengan menggunakan pendekatan andragogi sebagai salah satu strategi yang digunakan sebagai peningkatan kompetensi profesional peserta didik kursus dan pelatihan.

Menurut UU RI No 14 tahun 2005 pasal 10 ayat 1 dan PP RI No. 19 tahun 2005 pasal 28 ayat 3. Menyatakan kompetensi profesional diartikan sebagai kebulatan, pengetahuan, keterampilan, dan sikap yang diwujudkan dalam bentuk tindakan cerdas dan penuh tanggung jawab yang dimiliki seorang yang memangku jabatan guru sebagai profesi. Kompetensi profesional sendiri sangat berkaitan dengan kemampuan seorang individu untuk menguasai materi yang disampaikan dan juga memahami keilmuan lainnya. Karna dalam kompetensi profesional seseorang harus mampu untuk memahami materi yang di ajarkan, dan dari konsep tersebut dapat diaplikasikan dalam kehidupan seharihari.

Sehingga peningkatan kompetensi profesional seorang peserta kursus bisa lebih terarah dan lebih dikerucutkan lagi. Dalam hal tersebut peserta kursus mampu mengaplikasikan pemahaman yang di dapat dari hasil kursus kedalam kehidupan 
sehari-hari. Dengan kata lain dapat merealisasikan apa yang mereka dapat dan menjadi suatu ilmu yang bermanfaat karna mereka mampu berdaya setelah mendapatkan keterampilan dan pengetahuan.

Pendekatan andragogi menerapkan prinsip bahwa peserta kursus adalah seseorang yang sudah memiliki pemahaman, pengalaman yang luas, sehingga sebagai media peningkatan kompetensi profesional. Kompetensi yang dimiliki oleh peserta kursus sendiri sudah ada kemudian ditambah motivasi yang diberikan oleh pengelola atau fasilitator yang menambah semangat bagi peserta kursus tata busana. Kompetensi profesional merupakan spesifikasi bahwa setiap orang harus mempunyai tingkat keahlian yang lebih medalam. Knowles dalam Sudjana (2005) mendefiniskan andgragogi sebagai seni dan ilmu dalam membantu peserta didik (orang dewasa) untuk belajar (the science and arts of helping adult learn). Berbeda dengan pedagogi karena istilah dengan pedagogi karena istilah ini dapat diartikan sebagai seni dan ilmu mengajar anak-anak. Pendekatan andragogi merupakan strategi yang digunakan oleh pengelola lembaga kursus dalam peningkatan kompetensi profesional peserta kursus.

Untuk mengukur keberhasilan proses kursus dan pelatihan tata busana diperlukan adanya penilaian peningkatan kompetensi profesional melalui uji kompetensi pada tahap awal. Uji kompetensi ini merupakan cara untuk mengetahui tingkat keberhasilan peserta kursus. Sehingga akan terdapat perbedaan yang disignifikan yang dapat terlihat. Karna disini pengelola juga berperan sebagai fasilitator dan motivator dalam kelancaran kegiatan pelatihan yang di jalani. Teknik penilaian lain juga berupa tes tertulis berupa pertanyaan yang harus dijawab oleh peserta kursus pada tahap uji kompetensi. Tes tertulis ini berbentuk pilihan ganda dan uraian. Menurut Jihad (2008) tes tertulis merupakan tes dimana soal dan dan jawaban yang diberikan kepada peseta didik dalam bentuk tulisan. Penelitian ini bertujuan untuk memperoleh data tentang peningkatan kompetensi profesional peserta kursus tata busana melalui pendekatan andragogi.

Lembaga kursus dan pelatihan merupakan salah satu bentuk pendidikan nonformal yang diselenggarakan untuk masyarakat bagi mereka yang memerlukan keterampilan, pengetahuan, kecakapan hidup, dan kemampuan sikap untuk mengembangkan ketrampilan yang dimiliki. Menurut pasal 26 undang-undang no 20 tahun 2003 tentang sistem pendidikan nasional, pendidikan nonformal berfungsi sebagai pengganti, penambah, atau pelengkap pendidikan formal dalam rangka mendukung pendidikan sepanjang hayat untuk mengembangkan potensi peserta didik dengan penekanan pada penguasaan pengetahuan dan keterampilan fungsional serta pengembangan sikap dan kepribadian profesional.

Menurut Edwin B. Flippo (Kamil, 132 : 2012) "Pelatihan adalah tindakan meningkatkan pengetahuan dan keterampilan seorang pegawai untuk melaksanakan pekerjaan tertentu". LKP Srikandi merupakan lembaga kursus dan pelatihan yang memiliki program tata busana. Kursus tata busana merupakan suatu program yang mengahasilkan lulusan-lulusannya terus berdaya dan mampu memiliki keterampilanketerampilan dalam bidang tata busana. Setiap output biasanya dapat membuka usaha sendiri. Dengan menggunakan pendekatan andragogi sebagai strategi bagi pengelola dalam proses pelatihan. 
Berdasarkan latarbelakang diatas, rumusan masalah dari penelitian ini adalah untuk mengetahui apakah ada perbandingan peningkatan kompetensi peserta kursus tata busana antara sebelum dan sesudah adanya pendekatan andragogi. Tujuan dari penelitian ini adalah untuk mengidentifikasi pengaruh upaya pengelola lembaga kursus dan pelatihan dalam meningkatkan kompetensi profesional peserta kursus tata busana. Sementara manfaat dari penelitian ini yaitu: (1). Sebagai program yang dapat menjadi penguat suatu lembaga karna program tersebut menjadi program yang mampu memberdayakan masyarakat dan memberikan keterampilan khusus pada masyarakat. (2).Manfaatnya agar bisa memiliki referensi keterampilan yang sesuai dan bisa meningkatkatkan kompetensi yang dimiliki sehingga bagaimana caranya keterampilan tersebut dikembangkan.

\section{METODELOGI PENELITIAN}

\section{Jenis Penelitian}

Berdasarkan permasalahan yang diteliti metode yang digunakan dalam penelitian ini adalah metode deskriptif dan pendekatan kualitatif Mashyuri (2008) menjelaskan bahwa metode deskriptif merupakan penelitian yang memberi gambaran secara cermat mengenai individu, keadaan kondisi masyarakat sekitar.

Menurut Sugiono (2014) menjelaskan bahwa:

Metode penelitian kualitatif merupakan metode penelitian yang berlandaskan pada filsafat positivisme, digunakan untuk meneliti pada kondisi obyek yang alamiah, (sebagai lawannya adalah eksperimen) dimana peneliti adalah sebagai instrumen kunci, teknik pengumpulan data dilakukan secara triangulasi (gabungan), analisis dan bersifat induktif/ kualitatif, dan hasil penelitian kualitatif lebih menekankan makna dari pada generalisasi.

Metode deskriptif disini bahwa peneliti memberikan gambaran tentang LKP Srikandi sebagai tempat penelitian.

\section{Waktu dan Tempat Penelitian}

1. Waktu Penelitian : Januari- Februari 2018

2. Tempat Penelitian : Penelitian ini penulis laksanakan di tempat kegiatan belajar LKP Srikandi Kelurahan Padasuka Kecamatan Cimahi Tengah.

\section{Target dan Subjek}

Populasi dalam penelitian ini adalah peserta kursus tata busana di LKP Srikandi. Teknik pengambilan sample dalam penelitian ini menggunakan teknik probability sampling. Sample dalam penelitian ini yaitu peserta kursus tata busana. Penentuan jumlah sample dalam penelitian ini mengacu dari rumus yang dikembangkan oleh Krejcie dan Morgan. (Sugiono S. , 2014:9) Populasi adalah keseluruhan peserta tata busana dengan sampel lima orang peserta dengan menggunakan teknik wawancara. 


\section{Analisis data}

\section{Dokumentasi}

Dokumentasi digunakan utuk mendukung instrumen wawancara dengan menunjukan data dilapangan yang sudah ada. Dokumentasi hasil penelitian ini adalah hasil keterampilan tata busana. Diambil ketika proses pembelajaran berlangsung.

\section{Wawancara}

Wawancara digunakan sebagai teknik pengumpulan data. Wawancara dilakukan kepada sumber yang paling tahu, benar dan dapat dipercaya. Wawancara adalah kegiatan yang dilakukan oleh dua pihak dimana yang satu menjadi narasumber dan yang satu menjadi pewawancara dengan maksud memberikan penjelasan sesuai dengan masalah yang di teliti. Teknik wawancara yang digunakan oleh peneliti adalah wawancara terstruktur dimana peneliti sudah menyiapkan instrumen penelitian berupa pertanyaan-pertanyaan yang akan diajukan kepada responden yaitu pengelola LKP Srikandi dan juga peserta kursus tata busana. Sugiono H. d., (2014)mengemukakan bahwa anggapan yang perlu dipegang oleh peneliti dalam menggunakan metode interview dan juga kuisioner angket.

Instrumen penelitian menggunakan alat yaitu wawancara sebagai alat pengambil data, menggunakan teknik wawancara karena subjek yang dijadikan sampel dalam penelitian berjumlah lima orang, sehingga tidak memungkinkan menggunakan teknik pengumpulan data berupa angket.

\section{Prosedur Pengolahan Data}

Prosedur pengolahan data merupakan proses penting, oleh karna itu harus dilakukan secara benar. Data yang dikumpulkan kemudian diolah, yang termasuk kedalam kegiatan pengumpulan data ialah perencanaan, pengumpulan data, pengumpulan data dasar, pengumpulan data penutup dan melengkapi prosedur dari pengolahan data kualitatif berisi deskriptif tentang hal-hal esensial dari pertanyaan Syaodih (2008)

\section{PEMBAHASAN}

Dari segi perencanaan yang dilakukan oleh pengelola Lembaga kursus dan pelatihan Srikandi dalam meningkatkan keterampilan profesional peserta didik sehingga mampu menghasilkan output yang diharapkan mulai dari identifikasi kebutuhan, sarana dan prasarana, tujuan dan kebutuhan administrasi. Dari segi pelaksanaannya pengelola selalu memperhatikan peningkatan keterampilan yang didapat peserta didiknya setiap kali pertemuan. Melalui strategi dan pendekatan andragaogi yang diberikan kepada peserta didik yang mayoritas usia dewasa serta pendekatan secara individu. Hasil evaluasi sendiri melalui pengukuran uji kompetensi pada level ke satu program kursus sehingga penyebab terjadi peningkatan kompetensi profesional peserta kursus diantaranya: (1). Peserta kursus tata busana yang mendapatkan pendekatan andragogi dan pendekatan individu merasakan bahwa dalam pembelajaranya lebih efektif dan lebih mampu merefleksikan pengetahuan dari materi yang disampaikan dan mampu mengaplikasikan keterampilan dengan mudah. (2) munculnya motivasi peserta kursus terhadap kegiatan pelatihan yang dilakukan.

Seperti yang dijelaskan menurut Ansori \& Rosita (2018) "Perkembangan kekuatan ekonomi secara jelas dan nyata harus dikaji secara menyeluruh dan berkesinambungan 
dalam konteks pendidikan nonformal. Karena setiap program yang dilaksanakan membutuhkan kesesuaian antara kebutuhan hidup masyarakat dengan konteks kehidupan ekologi, baik dalam potensi biologis, potensi kehidupan non biologis, bahkan sistem tradisi yang hidup dan tumbuh subur di masyarakat. Dengan berbagai kekuatan ini, diharapkan PKBM dapat tumbuh menjadi pusat ekonomi masyarakat yang berkelanjutan."Tidak hanya PKBM disini LKP juga menjadi pusat ekonomi masyarakat dalam bidang keterampilan sehingga peningkatan keterampilan sangat dibutuhkan.

Adapun kelengkapan lain yang mendukung proses kursus dan pelatihan yang dilakukan oleh pengelola diantaranya adalah:

\section{a. Kemitraan}

Pengelola telah menjalin kerjasama dengan berbagai pihak, baik swasta maupun pemerintah. Pengelola melakukan kemitraan dengan DUDI (Dunia Usaha Dan Inustri). Dimana sebelumnya mereka diberikan bimbingan terlebih dahulu oleh pengelola dengan maksud mendapatkan pengetahuan tambahan berkaitan dengan DUDI, membantu masalah dalam proses pemecahan masalah. Tentunya kerjasama tersebut dapat menguntungkan satu sama lain, baik untuk lembaga maupun pihak yang bermitra. Karna bagi lembaga sendiri juga terdapat feedback yang sesuai. Hal ini sesuai dengan yang dikemukakan oleh (Kamil, 2010) bahwa jaringan kemitraan adalah suatu strategi bisnis yang dilakukan oleh dua pihak atau lebih dalam jangka waktu tertentu untuk meraih keuntungan bersama dengan prinsip saling membutuhkan dan membesarkan. Selain bekerjasama dengan DUDI LKP Srikandi juga bekerjasama dengan Dinas Sosial dalam rangka penyaluran lulusan kedunia industri atau juga dalam hal anggaran atau pembiayaan.

Jalinan kemitraan ini dilakukan oleh pengelola lembaga sebagai sarana agar lulusan dari LKP nya dapat tersalurkan dan bekerja di tempat tersebut. Cara yang dilakukan oleh pengelola berupa penyebaran informasi via media sosial. Dimana pengelola membuat suatu grup alumni peserta didik. Grup yang digunakan sebagai sarana berkomunikasi dan bertukar informasi yang bermanfaat.

\section{b. Kelengkapan sarana dan prasarana}

Berdasarkan hasil wawancara yang dilakukan oleh peneliti dapat disimpulkan bahwa pengelola selalu berusaha memfasilitasi peserta didiknya dengan peralatan yang memadai. Dari awal pelaksanaan kursus sampai di akhir uji kompetensi pengelola selalu mendampingi dan memafasilitasi dengan memberikan yang terbaik kepada peserta didiknya. Media yang diberikan untuk membantu peserta didik seperti modul yang berisi materi tentang dasar-dasar menjahit sampai memfasilitasi instruktur yang kompeten dan ahli dibidangnya. Kelengkapan sarana dan prasarana tersebut sudah disiapkan oleh pengelola ketika identifikasi kebutuhan peserta didik. Hal ini sesuai dengan yang dikemukakan oleh Daryanto (2008) prasana berarti alat tidak langsung untuk mencapai tujuan. Dalam pendidikan misalnya lokasi atau tempat, bangunan sekolah, lapangan olahraga, uang saku dan sebagainya.

Faktor sarana dan prasana merupakan faktor pendukung yang menunjang terlaksanya program kursus tersebut. Sehingga fasilitas harus memadai agar mampu mendukung 
dan dapat terlaksana sesuai rencana. Sehingga tidak diragukan lagi untuk kelengakapan sarana dan prasarana di LKP Srikandi sudah memadai dan membantu dalam proses pelaksanaan kursus dan pelatihan menjahit.

\section{c. Modal dan strategi}

Modal yang dimiliki adalah berupa ilmu serta fasilitas yang menunjang dalam pelatihan kursus. Berupa mesin jahit, peralat menjahit (jarum, pendedel, benang, gunting, meteran dan peralat lain yang mendukung). Serta fasilitator atau instruktur kursus yang kompeten.

Strategi yang digunakan oleh pengelola yaitu pendekatan personal sebagai bagian dari proses keberhasilan peserta didik, pemberian motivasi, memberikan pelatihan khusus dengan waktu belajar tambahan, dan pendekatan andragogi sebuah pendekatan pada orang dewasa yang menjadi peserta didik di LKP tersebut. Startegi ini merupakan langkah-langkah yang dilakukan pengelola dalam proses pelaksanaan sehingga dalam proses tersebut terjadi interaksi yang positif. Dalam melibatkan peserta didik, instruktur dan masyarakat, menjadikan program yang dilaksanakan berkembang sesuai dengan standar yang ditetapkan terutama dalam penguatan dan peningkatan kapasitas perekonomian warga belajar dan masyarakat, ini menjadi modal sosial (social capital) dalam pemberdayaan masyarakat melalui pendidikan (Mulyono, 2018).

\section{Kemampuan yang didapat oleh lulusan setelah mengikuti kursus di LKP Srikandi}

\section{a. Aspek kognitif (pengetahuan)}

Aspek kognitif adalah aspek pengetahuan berdasarkan fakta yang empiris yang di dapat oleh peserta kursus tata busana mengenai materi-materi yang didapat melalui modul yang di berikan oleh pengelola. Modul tersebut sebagai dasar atau acuan pada tahap awal mengikuti pelatihan kursus tata busana. Peserta didik mampu mengoprasikan dan mengenal peralatan menjahit dari modul tersebut. Kemampuan ini merupakan tahap dasar yang di rencanakan oleh pengelola dalam meningkatkan kompetensi profesional peserta kursus tata busana.

\section{b. Aspek afektif (sikap)}

Aspek afektif adalah aspek sikap seorang individu yang sudah memperoleh pelatihan atau kursus mampu memperlihatkan perubahan sikapnya. Dari awal mereka belum bisa mengoprasikan mesin jahit sampai mampu mengoprasikan dengan lancar dan tenang. Mampu merespon apa yang di instruksikan oleh instruktur dan pengelola dalam pelaksanaan kursus dan pelatihan. Bersikap sopan dan santun kepada instruktur meskipun usia mereka ada yang sebaya atau lebih tua dari instruktur. Mau merespon instruktur dan percaya diri untuk mampu mengoprasikan mesin jahit sendiri tanpa adanya bantuan dari instruktur. Hal tersebut bisa terjadi karna pengelola memberikan pendekatan andragogi sebagai strategi dalam proses pelaksanaan kursus dan pelatihan. Sehingga peserta mampu mengalami perubahan sikap dan prilaku kearah yang lebih baik atau dikehendaki oleh pengelola.

c. Aspek psikomotor

Aspek psikmotor adalah keterampilan yang dikuasai oleh peserta kursus tata busana dimana peserta kursus memahami materi yang didapat dan mampu mengaplikasikan 
keterampilan tata busana sehingga menghasilkan produk seperti kemeja, rok, celana. Peningkatan aspek psikomotor ini merupakan peningkatan kompetensi profesional yang diharapkan oleh pengelola karna kompetensi ini adalah keahlian yang harus dimiliki oleh seseorang dalam melaksana pekerjaannya.

Dapat disimpulkan dari ketiga ranah tersebut saling berkaitan dan terjadi pencapaian yang diharapkan oleh pengelola bahwa dalam proses pelaksanaan kursus dan pelatihan yang diberikan strategi atau pendekatan andragogi mampu memberikan keterampilan atau ketercapain ketiga aspek setiap peserta didik yang mampu mereka aplikasikan setelah mendapatkan pembelajaran. Sehigga lulusan atau output dari pelatihan kursus tata busana tersebut mampu memiliki kompetensi profesional yang mereka terapkan di kehidupan sehari-hari baik dalam dunia pekerjaan tertentu.

\section{KESIMPULAN DAN REKOMENDASI}

Upaya peningkatan kompetensi profesional yang dilakukan oleh pengelola LKP Srikandi sudah sangat optimal sehingga menghasilkan lulusan yang kompeten. Dengan tujuan mereka mampu menciptakan usaha sendiri dan mampu memenuhi kebutuhan hidupnya. Sehingga sumberdaya manusia yang mereka miliki dapat mereka manfaatkan melalui keterampilan yang mereka dapat. Kegiatan pengelolaan yang dilakukan oleh pengelola dari mulai perencanaan sampai pelaksanaan dan sampai evaluasi, menjalin kemitraan, menyiapkan sarana dan prasarana serta memberikan instruktur tata busana yang kompeten merupakan suatu hal yang pengelola berikan untuk peserta didiknya agar kegiatan kursus dapat terlaksana sesuai dengan harapan.

Peningkatan aspek kognitif peserta didik menghasilkan pengetahuan bahwa peserta didik yang awalnya belum bisa mengoprasikan mesin jahit dan mengenal perlengkapan menjahit jadi tahu. Aspek afektif dimana terjadi perubahan sikap individu kearah yang lebih baik yang diharapkan pengelola mereka mulai mau bertanya, merespon, adanya kepercayaan diri untuk mampu mengoprasikan mesin jahit sendiri tanpa didampingi oleh instruktur. Aspek psikomotor menjadikan peserta didik untuk mampu mengaplikasikan keterampilan yang dimiliki kedalam kehidupan sehari-hari.

Berdasarkan pada hasil pembahasan dan kesimpulan diatas maka peneliti memberikan rekomendasi bagi beberapa pihak antara lain;

a. Bagi pengelola

1) Memperluas jejaring kemitraan

2) Menambah instruktur tata busana

b. Bagi peserta kursus

1) Melalukan inovasi dibidang tata busana mengenai trand model pakaian atau tata busana yang selalu mengikuti perkembangan zaman

2) Memperluas jejaring

\section{c. Bagi peneliti}

Untuk penelitian selanjutnya bisa lebih memahami dan mendalami tentang pengelolaan di lembaga kursus dan pelatihan nonformal sebagai bahan perbaikan untuk penelitian selanjutnya. 


\section{DAFTAR PUSTAKA}

Ansori, \& Rosita, T. (2018). Increasing Economic Capacity Of Rural Community Through The Use Of Local Ecological Potency Based. Journal Of Nonformal Education, 4 (1) hal 89-96.

Ansori, A. (2018). meningkatkan kapasitas ekonomi masyarakat pedesaan melalui penggunaan potensi ekologis lokal berbasis. jurnal Pendidikan Nonformal, 93.

Ansori, T. R. (2018). Increasing Economic Capacity of Rural Community Through The Use Of Local. Journal of Nonformal Education, Vol 4 (1), 89-96.

Ardiwinata, J. S., \& Mulyono, D. (2018). THE STRATEGY OF MANAGERS IN MOVING BUSINESS LEARNING GROUP PROGRAM IN PKBM SRIKANDI CIMAHI CITY. Journal of Education Expert Vol 1 (1), 41-50.

Daryanto, D. (2008). Evaluasi Pendidikan. Jakarta: Rienika Cipta.

Direktorat PKBM Jawa Barat . (2006). Pusat Kegiatan Pembelajaran. Jakarta: Rineka Cipta.

Huraerah. (2006). Pemberdayaan Masyarakat. Bandung: Tarsito.

Jihad, J. (2008). Evaluasi Pembelajaran. Jakarta: Multi Press.

Kamil, M. (2012). Model Pendidikan dan Pelatihan (konsep dan aplikasi). Bandung: Alfabeta.

Korten dan Carner. (1993). Pemberdayaan Masyarakat. Jakarta: PT. Gramedia.

Mashyuri, M. (2008). Pengaruh Kualitas Pelayanan Terhadap Kepuasan Konsumen. Ilmu Administrasi Bisnis, volume 4 nomor 3, 20016 hal 34.

Mulyono, D. (2018). COMMUNITY EDUCATION IN THE DEVELOPMENT OF THE COMMUNITY. Empowerment, Vol 7 (1), 25-35.

Noe, Hollenbeck, Gerhart, \& Wright. (2003). Pelatihan dan Pengembangan Manusia . Jakarta : Rineka Cipta.

Soetomo. (2011). Pemberdayaan Masyarakat. Jakarta : PT. Gramedia.

Soewarman. (2007). Pemberdayaan Masyarakat. Bandung : Gunung Agung.

Sudjana, S. (2005). Metode Statistika. Bandung: Bumi Aksara.

Sugiono, H. d. (2014). Metode Penelitian Kuantitaif Kualitatif dan R\& D. Bandung: Alfabeta.

Sugiono, S. (2014). Metode Penelitian Kualitatif Kuantitatif dan $R \&$ D. Bandung: Alfabeta.

Sugiono, S. (2014). Metode Penelitian Kuantitatif Kualitatif dan R\&D. Bandung: Alfabeta.

Syaodih, N. (2008). Metode Peneltian Pendidikan. Bandung : Rosdakarya.

Winarno, S. (1981). Metode Penelitian. Jakarta: Rineka Cipta. 
